\title{
Framing social innovation research: a Sociology of Knowledge (SoK) Perspective
}

Frank Moulaert and Barbara Van Dyck

When quoting this paper, please refer to Moulaert, F, Van Dyck, B, (2013), Framing Social Innovation Research: a Sociology of Knowledge Perspective, chapter 3.5. in "International handbook on social innovation” Eds Moulaert, F., MacCallum, D., Mehmood, A., Hamdouch, A., Edward Elgar

\section{Introduction}

If social innovation (SI) is about transformation of institutions, overthrowing oppressive 'structures with power', collective agency to address non-satisfied needs, building of empowering social relations from the bottom-up, one can indeed wonder what leads scientists, who often have a strong theoretical interest and occasionally suffer from forum phobia, to social innovation analysis and social innovation practice, as advisors, theorists, activists, technicians, etc.?

Is it that social innovation scientists are aware that through their work of knowledge production they - consciously or un-consciously - defend or reinforce particular positions and interests in society? They seemingly make the choice to acknowledge the inherent positionality of (scientific) knowledge and make explicit their intention of knowledge production in the interest of marginalized or disempowered voices and with the purpose of social transformation.

SI research indeed is about 'changing the world' through study, cooperation and shared intervention or collective action, usually in a form of action research. Thinking about changing 'the' world necessarily implies questions about whose and which world to change? In social innovation research we thus need to look both at what is studied and how this is done. Or, as we argued in Chapter 1.1., the study of SI is intrinsically reflexive. In that regard, it also is remarkable that SI scientists, explicitly working in empathy and solidarity with interest groups, often seem to valorise the coexistence of a variety of perspectives in the definition of research questions and the ways to address them.

The confrontations of different perspectives and analytical instruments through alliances of practitioners, users, and researchers open the possibility to create new articulations and ways of knowing. Research practices that focus on socially innovative community building and policy making so contribute - as is shown in several chapters of this handbook - to transformations of social relations in and through knowledge production processes. Moreover, and despite their epistemic diversity, researchers and practitioners involved in SI research share a grand view of an institutionally complex world that is largely dominated by oppressive forces and opportunistic agencies, and which can only be countered through coordinated collective action.

In this chapter, we want to reconstruct the scientific practice of knowledge building within its complex institutional dynamics. To that purpose, we opt for a 'Sociology of knowledge (SoK) approach' which puts the scientists, scientific practice, theory building and methodology development in a societal context. A SoK perspective is a means to connect what we analyse to how we do analyse it. We will argue that a meta-theoretical framework hosting the main features of the social relations and cultural dynamics in which the knowledge productive is embedded, is productive in developing a SoK approach to social innovation research. It allows to reveal the relation between political conflicts or disagreeing opinions and fundamentally different approaches about truth, reality and knowledge, within a negotiated and shared view of the social, economic, cultural and political forces that shape societal transformation. Examples of such meta-theoretical frameworks can be found in Novy, 
Coimbra Swiatek and Moulaert. (2012) for the analysis of social cohesion in the city and in Moulaert (1987) for the analysis of local development institutions and strategies. Metatheoretical frameworks share a view of the world which they address - e.g. by identifying the predominant social relations ruling that world - while remaining sufficiently 'meta' as a dialogue space for a diversity of rationales, codes of behaviour, initiatives of action, etc.

\section{Scientific practice socially embedded, analytically unrolled: Sociology of Knowledge perspectives}

When after about twenty years of theoretical work and grassroots participatory research, questions emerged about the 'unity' of the social innovation argument, the necessity or the desirability of ' $a$ ' theory or ' $a$ ' paradigm of social innovation, the research community who worked on the projects IAD, URSPIC, SINGOCOM, VALICORES, KATARSIS and SOCIAL POLIS started collectively to reflect on the role of social science (theory, methodology, social utility) in social change debates, initiatives and analysis. ${ }^{1}$ Through these reflections, a number of philosophy of science concepts received a more grounded meaning.

\section{Epistemology}

Epistemology is an inquiry into, and a negotiated consensus on, the way to develop knowledge. It is not a doctrine of scientific knowledge creation. Epistemology is understood as an interactively unrolled manual on how to connect questions about social change to scientific interrogation (problématique), how to lead this interrogation, and to decide on the relative 'verity' or 'truth' of the answers. From the social innovation perspective, 'truth' is concerned about the (socially accepted) relevance of the scientific answers for the satisfaction of (non revealed) needs, the transformation of social relations, and the empowerment of populations and communities. The criteria for verity are therefore relationally conceived. Or, if we redefine epistemology "as about the achievement of the social legitimacy of the knowledge that is developed", social innovation epistemology is about the possibility to verify the (socially accepted) relevance of the knowledge for social transformation.. This relevance has to do with the recognition of the role of social forces and their discourses in the reproduction of scientific legitimacy and, therefore, with ontology. Before developing on the meaning of ontology in SI research, we briefly introduce structural-realism as a particular epistemological position in the study of social change.

\section{Structural-realist epistemological perspective}

An epistomological perspective in SI research has to start from the idea that knowledge is socially produced, i.e. that "it is neither an epiphenomenon of nature nor a convention of man" (Coimbra Swiatek 2011, p17). Secondly we believe that a real world exists independantly of our interpretation of it, which is referred to as the independence of reality from our knowledge. Furthermore we start from the idea of the fallibility and theory-based character of knowledge. This highlight the importance of frames of meaning to mediate

1 For an overview see www.socialpolis.eu 
understanding, their impact on outcomes and the need to understand external reality as wel its social construction. We find these features in structural realism.

We consider a structural-realist perspective as a particular stance within critical realism. A critical realist perspective, as summarised by A. Sayer (1984 [1992]), stresses that "the view of the world is differentiated and stratified consisting not only of events but objects, including structures, which have powers and liabilities capable of generalising events". This relates to a particular understanding of causation; emphasis is not on causation as such, but on causal powers or mechanisms. Causation then is studied not as a simple relationship between separate things or events. Instead the study is about what an object is like and will do under particular circumstances. Following this approach, the relationship between causal powers and their effect is considered contingent. This implies that for the study of SI we do not assume necessary, neither impossible, relations, but we look into the conditions, including events and structures, that make the transformation of socio-spatial relations possible.

To uncover the mechanisms causing historically contingent events, a stratified and differentiated ontology is required (Sayer 1984 [1992]). Structural realism then, as a particular focus within realism recognises a relative hierarchy among the objects of social reality and recognises structures in the form of relatively durable social relations as being of a potentially higher causal order. This does not mean that structures are pre-existing to social phenomena; in fact, structures are institutionally mediated and historically as well spatially reproduced through both collective and strategic individual action. Still the conceptual nature of structures, institutions and agency is pre-informed by the theory that has analytically conceived them. Coimbra Swiatek (2011, p18), following the Baskar tradition, refers here to the concept-dependent character of practices, institutions, rules, roles and relationships, "what they are depend on what they mean to the society and its members". The consequence is that within a critical-realist perspective several theories referring to the same or affine concepts should be confronted and brought into dialogue with each other . Moreover, and relevant for SI research, structural realism presupposes a strong and interactive relationship of theory and practice.

\section{Ontology}

Ontology in the theory of social change has to do with 'what world' is, is desired or is to be made. Theory of social change is based both on a view of what exists, the 'logic of being' and the potential of collectively becoming. Accounts of what exists in particular places and times, recognition of core features of society and ideas of desired change are essential in ontological reasoning. Ideas of desired change are in general important for motivating change agents. They can either be a view of the desired alternative (generic or detailed), or a utopia, a futurible; or a procedural view of how we can move on for betterment, a mapped-out genesis of alternative becoming in which all relevant actors are involved (transdisciplinarity).

This tension between the 'logic of being' and the 'logic of becoming' is an issue in social theories addressing social change, transformation or innovation. A very straightforward example is neoclassical economic market exchange theory, which uses a normative view of 'the self-adapting market as the ontology of equilibrium' as a hypothesis to test how the market actually functions. In the 'desired' neoclassical economic world each agent is an optimiser and has the information and behavioural skills to optimise its individual behaviour, thus contributing to the social equilibrium. In empirical orthodox economics, then, this aspired ontology is used to test actual economic behaviour in actually existing markets where such optimality principles are only occasionally applied and, if they do, only in a socially (structurally, institutionally) mediated way, i.e. in an environment not meeting the assumptions of the neoclassical mental construct. The market Utopia is taken for real and by 
assuming that it exists or can be materialised overnight, its normative principles are translated into policy measures which lead to several of the socioeconomic failures we have known over the last few decades (implosion of the virtual economy, recurrent and deepening financial crises, ....).

It is therefore very important to make clear distinctions between approaches to the 'construction of ontologies' relevant to social innovation (Moulaert and Nussbaumer, 2008, p. 131). ${ }^{2}$ A distinction should be made between:

(1) An ontology (of the existent or desired) as the basis for a theory or meta-theoretical framework;

(2) Ontogenesis or process of genesis of the vision of the existent or the desired (images of the future);

(3) 'Flat ontology', either an ontology of a homogenous society, or an 'open' ontology which as in e.g. a Deleuzean approach opens itself to a gradual complexification through interaction between agents;

(4) Structural-realist view of social reality: view of society recognising the structure of the economy, the political world, etc. significantly influenced by power relations and the way it constrains or facilitates collective agency..

We can apply these distinctions to territorial development and social innovation through community development (Figure 1) (see Chapters 2.4 and 6.3). Integrated Area Development (IAD), as an example adopts a structural-realist ontology of a complex world dominated by social structures (capitalist economy, politics dominated by masculinity and power relations) within which institutions are reproduced in a dialectal interaction between agency and structural transformations. Such an ontology reflects the visions of society and (its) communities as starting points for theorisation. But it also integrates the ontogenesis as an interactive process of actors (re)producing images of society, its components and their modes of functioning. The initial view of the world (initial ontology), the ontogenesis and the ontologies developed by the social forces and the territorial actors are linked to each other.

\begin{tabular}{|l|l|l|}
\hline $\begin{array}{l}\text { Societal Structure } \\
\text { Ontological Perspective }\end{array}$ & Flat ontology (3) & Structural-realist (4) \\
\hline Ontology (1) & $\begin{array}{l}\text { Neoclassical theory of } \\
\text { regional growth } \\
\text { TIM }\end{array}$ & $\begin{array}{l}\text { Social Region } \\
\text { IAD }\end{array}$ \\
\hline Ontogenesis (2) & $\begin{array}{l}\text { Deleuzean approach to } \\
\text { spatial development } \\
\text { Assembly theory }\end{array}$ & IAD \\
\hline
\end{tabular}

Figure.1 Ontogenesis, ontologies as applied to theories of territorial development Source : Moulaert and Nussbaumer, 2008, p. 131

Coherent with the socially embedded epistemological stance for SI analysis, the four concepts (ontology, ontogenesis, flat ontology and structural-realism) have analytical relevance by themselves, but should also be connected to each other. In SI research, the ontology of the existent and the desired is filled in through a transdisciplinary approach involving concerned agents and organizations. The genesis of the views of the existent and desired world themselves are therefore approached as a social process, never reaching final 
completion and repeatedly critically reinterpreted as to their relevance to collective action (see chapter Chapter 6.2 on holistic research and pragmatic collective action).

\section{Meta-theory or Meta-theoretical framework.}

Meta-theory or meta-theoretical frameworks are the logically next concepts that have popped up in social innovation epistemological discussions. Meta-theory as theory of theories; or as a theory of theorising (in sociology); or as an epistemological framework with a shared ontology and basic concepts - an overarching theoretical perspective; or more simply, the need for epistemic reflexivity : are the concepts and theories we are using pertinent to our problematic? And how can we select 'a framework to host theories' that would help us to answer this question? And should this meta-theory also reflect on the role of scientific practice in social reality and social transformation? As we argued in Chapter 1.1 ontological coherence in SI research indeed requires a reflexive positioning of the researchers in the SI research and action. This means that research agencies have to be conceptualised in the metaframework (and in some of the theories it hosts) to allow to evaluate their role in the action research as it goes. For example, by theorising the agents in the knowledge-building complex of the society for which SI is pursued, it becomes possible to figure out what their role could be in building alliances for new urban policy: will it be instrumental to mainstreaming caring liberalism in neighbourhood development or will it instead advice and empower radical change agendas?

Therefore, within a concern of analysing SI it is epistemologically coherent to state that a relevant meta-theory should be based on an ontology and ontogenesis that involve relational complexity as well as all relevant types of agency that make or seek social innovation, or make it work Ontogenesis, or the process of genesis of the vision of the existent and the desired, then becomes intrinsically transdisciplinary, putting implicated parties/actors at its heart. A meta-theoretical structure hosting roles of scientists and science in society is an important element in building a sociology of knowledge approach.

\section{The role of science and scientific knowledge building in contemporary society}

The foregoing paragraphs dealt with criteria of verity and truth seeking in knowledge production. We now put the knowledge production process in SI studies in a societal context that could reveal its relational complexity. This societal context can then serve as a starting point for building the meta-theoretical framework that is essential to the SoK approach in SI research.

In contemporary society, with its blurred boundaries between state, market and civil society, looking at and rethinking the role of science and scientific knowledge building is crucial in understanding and enacting social transformations. Moreover, if scientific knowledge, following the enlightenment logic, may have appeared to provide the truth, standing above other forms of knowledge, scientific knowledge itself becomes now part of public debate (Stengers 2006).

Especially in what Latour (1998) refers to as 'matters of concern' or issues that matter to people, citizens voice claim§s for a more democratic and transparent treatment of science and its claimed verities. Practitioners and citizens who no longer believe in the myth of progress, claim recognition for their part in complex knowledge-building processes. The allegory of the Cave - according to which scientists have the privilege to swap between the social world and free themselves from the tyranny of the social on order to access the 'truth' (Latour 2004) - has become obsolete. Many researchers have come to or are forced to realise that they are part of a complex world, in which society no longer simply rejects or accepts the 
results of Science. Citizens seek to participate in formulating research questions and in numerous cases, feel entitled to participate in setting research agendas (Miciukiewicz et al. 2012). Scientists become one actor, next to others, that add ingredients to questions about complex political issues. Next to classic scientific quality-criteria of validity and reliability, the social robustness of knowledge production becomes essential in the scientific validation process. For SI research, which typically studies innovation in social and political relations, through innovative participatory processes, this is particularly relevant.

In the epistemology section, we stressed the importance of the achievement of social legitimacy of SI knowledge and the possibility to verify the relevance of knowledge for social transformation. Achieving social robustness requires social legitimacy of knowledge and processes of democratizing knowledge (Nowotny 2003; Chapter 6.1 in this volume Novy et al.). Social robustness as a matter of fact involves the recognition of 'local knowledge' or 'lay knowledge' as valid knowledge as well as the approval of validity and truth of knowledge beyond university communities. In addition to 'peer review' practice - the process of internal knowledge validation - validation of knowledge is continuously negotiated with concerned parties. These can be practitioners, citizens, people in socially fragile conditions, technical experts, scientists from different disciplines.

Such processes where knowledge-building explicitly materialises through the interaction of science and society is referred to as transdisciplinary research (Cassinari et al. 2011). The cooperation of scientists, practitioners and lay people from diverse backgrounds does not erase disciplinary boundaries. On the contrary, the specificities of diverse practices (including different scientific disciplines) are brought together in their heterogeneity. The possibility for innovation is created in the articulation of contrasting perspectives. In contrast with classic positivist science approaches, these hybrid knowledge platforms have the intrinsic uncertainty of knowledge at the very heart of their concerns. Knowledge as well as the very knowledge production process, consequently, are continuously debated. Issues as social cohesion and territorial development in particular do not confront us with static problems that can be answered through linear problem-solutions rationalities, neither do they lead to generalizable problems nor solutions (Novy, Coimbra Swiatek and Moulaert 2012).

Obviously, relations of science and society have always existed. Scientific, political and economic elites have always been closely related, patterns of interaction and influence change though. Changes in context, content and organisation of knowledge production are reflected in an increased emphasis on science driven by practical applications, strong influence of the market, temporary knowledge alliances and heterogenous research organisations (Hage, Leroy, and Petersen 2010). As in other sectors of society, research governance should take the form of more horizontal networks, and quality becomes a process controlled through a number of stakeholders.

However this 'horizontalization' of research governance does not guarantee transdisciplinarity as meant in social innovation research. Transdisciplinary research, as practiced in social innovation analysis, differentiates itself from many other knowledge production related institutional arrangements of the knowledge economy in several ways. Firstly, the participants in research communities that are involved in the definition of research questions and research methods have joint interests that are not commercially oriented. Research participants in fact are usually not financially empowered, nor do they have necessarily access to cutting edge scientific knowledge. Secondly, the relation between researchers and lay people is not based on the distinction of 'those who know' (the scientists) and 'those that have to be convinced' (the people). Relations are based on the recognition of the diversity of valid knowledges that have to be brought together as a potential for socially relevant, legitimate and valid knowledge. Third, and this stems from the first two observations, the content of the knowledge-building process is oriented towards facing challenges of social and socio-ecological empowerment. 


\section{Sociology of Knowledge}

The epistemological stance, the view of ontology/ontogenesis and the introduction of a metatheoretical framework capable of hosting the role of scientists/science in the transformation of society spelled out before, come close to the sociology of science approach implicitly or explicitly defended by J. Schumpeter, inspired by Scheler (1926 [1921]) and Mannheim (1936 [1931]). According to Shionoya (2004), for Schumpeter sociology of science $[\ldots]$

'views science as social activities influenced by the historical, social and cultural context of the time' (p. 340).

In the structuro-realist epistemological logic, the construction of concepts and theories of social innovation must be assessed within the societal framework in which they have been developed. Relational knowledge-production processes in which communities of scientists and other concerned parties cooperate facilitate the construction of concepts and theories that may be able to address societal issues. Moreover, according to Schumpeter's vision on science and as elaborated earlier, knowledge is not a monopoly of science, but the object of [also] other forms of knowledge formation and social practice that all have a place in the dynamics of development. Schumpeter develops arguments explaining that development should be analysed not only within a broader or general societal framework, but that the different spheres, dynamics and agency domains of society are entitled to their own sociology which together should allow to better understand the complex(ity) of development and its dimensions (knowledge, culture, economy, ...)

'Accordingly, next to economic sociology Schumpeter also has in mind a sociology of knowledge, a sociology of arts, and a sociology of the political, all of which help understand the energy and the mechanism of development, not just in general but also in each particular sphere. The question how the sociological insights in each particular sphere can be combined into a perspective that conveys the understanding of a modern, i.e., differentiated, whole, was also Schumpeter's central concern when he attempted in TWE (1911) to grasp the overall tendency of the socio-cultural development of a people' (Becker et al. 2005, p. 9)

Obviously, if we accept the reasoning about the role of the sociology of knowledge in (the study of) scientific practice (Scherer, Mannheim, etc.), there is no unique sociology of knowledge, and the terms of a sociology of knowledge are largely determined by the theory of society and social transformation to which it refers. Or, from a structural realist perspective, these terms are spelled out in the meta-theoretical framework of society, the view of scientific practice, the ontology it is related to and which gives a significant role to structural dynamics in explaining change and development, etc.

We consider the literature on the sociology of knowledge as a continuum in evolution. Mannheim is a precursory voice in a social-scientific process that could be labelled as the (re)making of the sociology of knowledge. He has understood that the relationships between ideology and scientific practice cannot only be studied through the lens of philosophy but that a sociological perspective is needed. In simplified terms, Mannheim's 'sociology of knowledge' approach follows two tracks. One more 'societal track' runs close to the Marxist way of looking at ideology formation; the other one lies closer to Scheler's micro-sociological analysis of knowledge institutions and practices. Knowledge for Mannheim is real, i.e., what 
is considered to be knowledge: knowledge that is socially or individually produced, but socially accepted as being knowledge.

Following David Bloor (1991) we could make a distinction within SoK between 'a weak programme' and 'a strong programme'. With the 'weak programme' addressing the process of knowledge creation in the limited sense: how has the relational process that led to knowledge been unrolled? Which have been the factors that have influenced the relationship between verity and bias? In the weak programme the context of intellectual activity is recognised, the potential ideological bias allowed for, but no room is given to the analysis of the activity of Reason, its deductions and inductions. The 'strong programme' in contrast, and which we refer to as 'complete embeddedness', includes: the social, political and economic context that nourished the environment in which [the] knowledge was developed, the sociocultural [including ideological] background of the scientists, their belonging to scientific and philosophical communities, the links between scientific practice and collective action, etc.

More instrumentally or positivist oriented scientists would argue that the strong programme involves 'everything' and therefore is unrealistic to pursue. This is no so, however.

First, it is clear that, following Mannheim's line of argument, that the 'strong programme' cannot be applied without clear epistemological positioning about how to address the role of knowledge production within society. The position we adopt here, we said, is a structural realist perspective. Scientific practice is situated with the structural dynamics of a society, e.g. as part of the knowledge infrastructure confirming the technocracy of the market economy and top-down governance systems; but also as part of counter hegemonic movements and practices of social innovation seeking to transform society and its communities in the direction of human development (Chapter 1.1 in this book). The strong 'sociology of knowledge perspective' fits very well this structural realist perspective on science and knowledge production and how it should be reflexively addressed.

A theory privileging the analysis of structures in social reality then can serve as a meta-theoretical framework hosting different epistemic viewpoints and practice-oriented interrogations. It sets the borderlines within which particular objects and their relations can be analysed. Examples of such approaches are well-known in critical geography and spatial development analysis, where the meta-theoretical framework starts from the social structures analysed in political economy - and often treats these structures as a main feature of the metaframework's social ontology (Chapters 1.1 and 2.1 in this Handbook).

Second, the focus is not on 'everything' but on the practices, institutions and socialization dynamics of scientific knowledge production, as embedded within societal dynamics. This consists for example of insights in the funding mechanisms of research to understand the relations between the goals of research funders, the research questions developed and preferred research methods. Another point of interest would be the social position of academics in society, and the way and type of expertise consulted in political decision-making. This is also why we believe that scientific agency should be conceptualised as a component of the meta-theoretical framework.

Third, we are looking at scientific practices producing knowledge about or related to social innovation. This means that, within the structural realist perspective and the "view of the world' it adopts, interrogations, concepts and theories that address these, will be privileged. These interrogations, concepts and theories will often stem from experience of action researchers or hybrid knowledge platforms (e.g. Social Polis); but also from scientific work such as critical literature surveys, action and policy oriented research from the past, etc.

Finally (for the time being) we examine these practices within their macro and micro social relations, with a particular focus on the communities, social and cultural environments, political arenas and fields of social integration and exclusion in which the knowledge institutions and scientists are involved. 
Already during the IAD (Moulaert 2000) and SINGOCOM projects (Moulaert et al. 2011), and from the beginning of KATARSIS (MacCallum et al. 2009), we looked at a variety of theories analysing and building-up social innovation processes, strategies, agendas. We have addressed these theories questioning their purpose: why were they developed? And according to which organizational and procedural dynamics? In a way this was the start of a SoK approach to these theories, which now can be further developed now from the point of view of the 'strong' SoK programme.

From the perspective of the 'strong' SoK, the socio-political dynamics in which the scientific debate/contribution takes place and, more precisely, the links with collective action within society and communities undertaking local development action should be addressed. These socio-political dynamics should be brought in connection to politico-ideological dynamics typical of the society and the community in which the knowledge production occurs.

But concerned about relevance of 'acquired' scientific knowledge for contemporary SI initiatives and processes, we also need to address the challenges of the present - how can contemporary SI research and action benefit from a SoK assessment of old theories? And what about a SoK assessment of emerging theories and methods? And how does historically and institutionally embedded knowledge be(come) relevant to SI innovation challenges/strategies/processes today?

Relevance for these exercises can be found in comparing contemporary societal dynamics (an "open" SOK approach) with those in which the 'old' theories were developed. In this way 'new' theorizing addressing contemporary challenges with their own philosophical debates and change movements, can be analysed partially by comparing them theory building process in an institutionally and politico-ideologically comparable past.

\section{Illustration of a SoK-approach at work}

Table 1 can be used as a 'macro' guide to lead it. The table gives five dimensions that are relevant to SoK analysis. This is a non-exhaustive list, but at least gives a good impression of what could be done in a balanced SoK approach according to the 'strong programme'. The table has selected three families of theories that are relevant for local development through SI today (Chapter 2.4): Theories of human endogenous development; Social Innovation theories ('style sixties'); and Integrated Area Development. The following paragraphs illustrate the operationalisation of a 'strong' SoK approach to social innovation theories of the 1960s (for an overview see Chambon et al. 1982).

SI analysis in the 1960s (and 1970s) should be situated in the context of the social movements and philosophies reacting against the hierarchy of capitalism and the state. The stress was very much on the democratisation of institutions, sexual liberation, gender equality, respect for different cultures (multi cultural society), etc. Quite a bit of the socio-political discourses considered as typical of the 1960s movements could be considered as anticipatory to the post-modern philosophies, research agendas, and collective as well as individual actions. Typical for the period are the relations between scientific communities (philosophers

like Sartre, visionaries like Attali, etc.) and workers as well as student organizations. The diversity of theoretical contributions in the field of social innovation reflects the diversity of the change agendas put forward by these organizations covering transformation of society, aspects of governance, emancipatory practices, institutional change, democratization of the educational system, humanization of welfare services, etc. 
The intellectual work on social innovation in the 1960s/1970s reflects to a large extent intellectual traditions concerned about individual rights within an equitable society: social liberalism, anarchism, communitarian socialism, ... But at the same time it is concerned about the future of 'big organizations' and 'heavy institutions', making proposals to democratise them. This concern holds the modernist insight that complex societies cannot be governed without human-made governance organizations, other than the market. Thus, in a way, the social innovation analysis of the 1960s/1970s anticipated the badly needed synthesis between postmodern decentralised creativity on the one hand, and the positive lessons drawn from the modernist governance of a complex society with its large scale institutions. Thus the theories developed in those days are potentially quite relevant for theorising and designing social innovation today. Still the different ideological climate, the dismantling of many fordist institutions, the growing role of decentralised initiatives in the contemporary contexts should be taken into account. They will necessitate e.g. reflections on bottom-linked governance (see Chapter 2.2), the growing role of local and regional agencies and institutions in socially innovative initiatives (Chapter 2.4) as well as the increased significance of ecological priorities and arenas (Chapter 2.3). Yet there are quite some similarities between the bottomup social movements that animated the heydays of the revolutionary sixties and the political movements of the contemporary times. Even if diverse issues beyond the class struggle gain in visibility, the building of decentralised alliances against oppressive powers and structures, and the believe in collective agency for social change remain. 
Table 1. Sociology of knowledge on social innovation and local development: Illustration of the approach through three (families of) theories

\begin{tabular}{|c|c|c|c|c|c|}
\hline $\begin{array}{l}\text { Dimensions addressed in } \\
\text { SoK } \\
\text { Theory/School/Approach }\end{array}$ & $\begin{array}{l}\text { Socio-cultural periods : dominant } \\
\text { philosophies, political regimes } \\
\text { (and scientific themes stressed) }\end{array}$ & $\begin{array}{l}\text { Relations with dominant } \\
\text { scientific epistemologies- } \\
\text { Problematic addressed }\end{array}$ & $\begin{array}{l}\text { Scientific communities to } \\
\text { which the researchers belong }\end{array}$ & Relations with collective action & 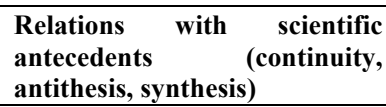 \\
\hline $\begin{array}{l}\text { Theory of human } \\
\text { endogenous } \\
\text { development } \\
(1970 \ldots . . .)\end{array}$ & $\begin{array}{l}\text { End of three decades of 'golden } \\
\text { age', continuation of the values of } \\
\text { the Welfare State at local level } \\
\text { Mixed Economy } \\
\text { Ideology of human progress } \\
\text { Themes : empowerment, } \\
\text { mobilisation of endogenous } \\
\text { resources, bottom-up development }\end{array}$ & $\begin{array}{l}\text { Respond to the need of unequal } \\
\text { spatial development that } \\
\text { emerged from the economic } \\
\text { crisis (half of 1970s) } \\
\text { Refutal of neoclassic theories of } \\
\text { regional development }\end{array}$ & $\begin{array}{l}\text { Economists of } \\
\text { international development } \\
\text { (back to the source...) } \\
\text { 'Spatial' social sciences } \\
\text { 'Old' institutionalists (influence } \\
\text { of German Historical School } \\
\text { (GHS)) }\end{array}$ & $\begin{array}{l}\text { Expertise, cooperation with local } \\
\text { communities and development } \\
\text { agencies... }\end{array}$ & $\begin{array}{l}\text { Continuity : theories of } \\
\text { development GHS, years 1960+ } \\
\text { (Myrdal, Perroux, Hirschmann) } \\
\text { Antithesis : development theory } \\
\text { confronted to growth theory } \\
\text { Synthesis : integration GHS, } \\
\text { theory of development and } \\
\text { empowerment, emancipation } \\
\text { theory (Friedmann 1992) }\end{array}$ \\
\hline $\begin{array}{l}\text { Social innovation } \\
\text { theories ('sixties') }\end{array}$ & $\begin{array}{l}\text { Sixties }+ \text { large pluralistic } \\
\text { and } \\
\text { movements } \\
\text { (progressive liberalism, } \\
\text { democratic Marxism) } \\
\text { Themes : anti-authoritarianism, } \\
\text { democratisation of institutions, } \\
\text { participation, social rights, social } \\
\text { innovations }\end{array}$ & $\begin{array}{l}\text { Reply to the excesses of } \\
\text { capitalism and mercantile } \\
\text { statism. } \\
\text { Try to ways to overcome socio- } \\
\text { economic inequalities. } \\
\text { Dissent with modernisation } \\
\text { theories (economy, state), rise } \\
\text { of post-modern theories } \\
\text { claiming creation of space for } \\
\text { bottom-up emancipation. }\end{array}$ & $\begin{array}{l}\text { Philosophical circles, } \\
\text { alternative economists }\end{array}$ & $\begin{array}{l}\text { Workers and student } \\
\text { mobilization } \\
\text { Reflexion groups on social } \\
\text { transformation in different spheres } \\
\text { and institutions of society. } \\
\text { Participation to social-democratic } \\
\text { governments (democratization of } \\
\text { education, redistribution of } \\
\text { income, social services) }\end{array}$ & $\begin{array}{l}\text { Continuity: links with social } \\
\text { liberalism, anarchist theories, ... } \\
\text { Antithesis : } \\
\text { postmodernism versus } \\
\text { modernism } \\
\text { Synthesis: attempt to correct } \\
\text { excesses of modernist } \\
\text { institutions, growing disillusions }\end{array}$ \\
\hline $\begin{array}{l}\text { Integrated } \\
\text { Development }\end{array}$ & $\begin{array}{l}\text { Eighties : rise of administrative } \\
\text { decentralization, local social } \\
\text { movements focused on life quality, } \\
\text { sustainable development, } \\
\text { improvement of life quality in } \\
\text { deprived neighbourhood. } \\
\text { Themes: local democracy, } \\
\text { territorial development (instead of } \\
\text { functional), inclusion of 'new poor' }\end{array}$ & $\begin{array}{l}\text { Respond to the needs of } \\
\text { deprived neighbourhoods and } \\
\text { their disempowered inhabitants. } \\
\text { Refutal of theories / ideologies } \\
\text { stressing positive effects of } \\
\text { globalization, economic } \\
\text { deregulation and flexibilization } \\
\text { of labour market }\end{array}$ & $\begin{array}{l}\text { Reflexion groups in urban } \\
\text { sociology, social economics, } \\
\text { spatial planning, political } \\
\text { science, urban and rural } \\
\text { anthropology. } \\
\text { Important role for action } \\
\text { research. }\end{array}$ & $\begin{array}{l}\text { Scientists involved in social } \\
\text { movements project teams } \\
\text { Experts and actors involved } \\
\text { in local partnerships. }\end{array}$ & $\begin{array}{l}\text { Continuity: links with social } \\
\text { innovation theories of } 1960 \\
\text { Antithesis: theories which } \\
\text { integrate the different } \\
\text { dimensions of territorial } \\
\text { development, moving beyond } \\
\text { functionalism (Moulaert 2000) } \\
\text { Synthesis: integration of TIM } \\
\text { elements. }\end{array}$ \\
\hline
\end{tabular}

Source: Moulaert and Nussbaumer (2008) 


\section{Conclusion}

A SoK approach to social innovation analysis shows how the contributions in this Handbook, besides their value for public debate and knowledge production on issues as social cohesion and community development, deal with a fundamental scientific yet socio-political debate. Through transdisciplinary work on matters of social concern, science itself becomes an issue of social innovation. The contributions give flesh and body to democratising the future for scientific activity in a context of blurred boundaries between the spheres of the state, the market and civil society. They propose ways to foster knowledge alliances that resist the privatization of knowledge and knowledge production to the benefit of private interests in a context where the majority of public institutions comply with the pressure for market-conform restructuring.

The SoK approach could be considered the intellectual watchdog of the knowledge alliance approach presented in Chapter 6.2. It provides a guideline for the reading of theory in its past context, while looking at its relevance or feasibility for addressing SI challenges today. From a structural-realist perspective it puts forward criteria to develop an appropriate meta-theoretical framework which can guide the SoK exercise in a self-reflexive manner, by placing the researchers in their different roles within the world they are supposed to analyse and live in. In this way, from the perspective of the role of science in social change and social innovation, the SoK approach speaks to the various grand challenges of society and communities today. And it does so by linking the lessons of the past (theory, practice, reflection, ...) to the possibilities for the present and the future.

\section{References}

Becker, M.C. and T. Knudsen (2005 [1932]), 'Translation of and introduction to «Entwicklung » (J. Schumpeter)', Journal of Economic Literature, 43 (1), 108-120.

Bloor, David (1991 [1976]), Knowledge and Social Imaginary, Chicago: University of Chicago Press.

Cassinari, D., Hillier, J., Miciukiewicz, K., and A, Novy, (2011), Transdisciplinary Research in Social Polis. Leuven: Social Polis. Available at: www.socialpolis.eu

Chambon, J.-L., A. David et J-M. Devevey (1982), Les innovations sociales, Paris: Presses Universitaires de France.

Coimbra Swiatek, Daniela (2011), Governance in new European regions: the case of Centrope. Doctoral Thesis presented to the Vienna University of Economics and Business, Institute for the Environment and Regional Development, Vienna.

Novy, A., D. Coimbra Swiatek and F. Moulaert (2012), 'Social Cohesion: A Conceptual and Political Elucidation', Urban Studies, 49 (9), 1873-1889.

Friedmann, John (1992), Empowerment. The politics of alternative development, Cambridge: Blackwell.

Hage, M, P. Leroy, and A. Petersen (2010), Stakeholder participation in environmental knowledge production, Futures, 42(3), 254-264.

Latour, Bruno (1998), 'Essays on science and society: From the World of Science to the World of Research?' Science, 280, Issue 5361, 208-209.

Latour, Bruno (2004), Politics of Nature: How to Bring the Sciences into Democracy. 
Cambridge, MA: Harvard University Press.

Mannheim, Karl (1936 [1931]), 'The Sociology of Knowledge', Ideology and Utopia, London: Routledge and Paul Kegan, pp. 237-80.

MacCallum, D., Moulaert, F., Hillier, J. and S. Vicari (2009), Social Innovation and Territorial Development, Farnham: Ashgate Publishing.

Miciukiewicz, K, F. Moulaert, A. Novy, S. Musterd, and J. Hillier (2012), 'Introduction: Problematising Urban Social Cohesion: A Transdisciplinary Endeavour', Urban Studies, 49 (9), 1855-1872.

Moulaert, Frank (1987), 'An Institutional Revisit of the Storper-Walker Theory of Labour', International Journal of Urban and Regional Research, 11 (3), 309330.

Moulaert, Frank (2000), Integrated Area Development in European Cities, Oxford: Oxford University Press.

Moulaert, F. and J. Nussbaumer (2008) La logique sociale du développement territorial, Québec: Presses Universitaires du Québec.

Moulaert, F, E. Swyngedouw, F. Martinelli and S. Gonzalez eds (2011), Can Neighbourhoods Save the City? Community Development and Social Innovation; London: Routledge.

Nowotny, Helga (2003), 'Dilemma of expertise. Democratising expertise and socially robust knowledge', Science and Public Policy, 30(3), 151-156.

Sayer, Andrew (1984 [1992]), Method in Social Science. A realist approach, London and New York: Routledge.

Scheler, Max (réd.) (1926 [1924]). Versuche zu einer Soziologie des Wissens, Munich: Duncker und Humblot.

Shionoya, Yuichi (2004), 'Scope and Method of Schumpeter's universal social science: economic sociology, instrumentalism, and rhetoric', Journal of the History of Economic Thought, 26 (2): 331-347.

Stengers, Isabelle (2010), La vierge et le neutrino: les scientifiques dans la tourmente, Paris : Les empêcheurs de penser en rond. 